\title{
Impact of Different Preplant Cultural Treatments on Survival of Phytophthora nicotianae in Soil
}

\author{
M. E. Matheron and M. Porchas, The University of Arizona, Yuma Agricultural Center, Yuma 85364
}

\begin{abstract}
Matheron, M. E., and Porchas, M. 2009. Impact of different preplant cultural treatments on survival of Phytophthora nicotianae in soil. Plant Dis. 93:43-50.

During the life of a citrus planting, the population of Phytophthora pathogens can build to significant levels in orchard soil. A study was initiated to examine the impact of some nonchemical cultural practices on survival of P. nicotianae, the most prevalent Phytophthora sp. in Arizona citrus groves, in soil formerly planted to citrus. In three trials over a 3 -year period, $P$. nicotianae could not be detected at a depth of $10 \mathrm{~cm}$ after soil naturally infested with the pathogen was subjected to a dry summer fallow period of at least 31 days in the desert southwest region of Arizona. The mean temperature of soil at this depth during these trials ranged from 37 to $39^{\circ} \mathrm{C}$. Furthermore, in two of these trials, after summer dry fallow periods of 38 and 45 days, the pathogen could not be detected at a depth of 15 to $20 \mathrm{~cm}$ and was detected in only one of 19 soil samples at a depth of 25 to $30 \mathrm{~cm}$. In comparison, the pathogen was recovered from a high proportion of soil samples subjected to a dry winter fallow period or maintained in the greenhouse and planted with a seedling of citrus, alfalfa, or irrigated without the presence of any plant, where mean temperature of soil ranged from 15 to $30^{\circ} \mathrm{C}$. In regions with a hot and dry summer climate, a dry summer fallow treatment of soil after removal of an existing citrus planting and before establishment of a new grove could provide a rapid and relatively inexpensive means of lowering the population of $P$. nicotianae to virtually nondetectable levels to at least a depth of $30 \mathrm{~cm}$.
\end{abstract}

Phytophthora gummosis and root rot is an economically important disease of citrus trees (7). The cited causal agents of this disease in the United States are Phytophthora citrophthora (R.E. Sm. \& E.H. Sm.) Leonian and P. nicotianae Breda de Haan (syn. P. parasitica). Both oomycete pathogens are cited as important citrus pathogens in Arizona (16) and California (8), whereas $P$. nicotianae alone is the primary pathogen on citrus in Florida (26) and Texas (24). Although both pathogens are present in Arizona citrus groves, $P$. nicotianae is much more prevalent than $P$. citrophthora (16).

Infection of citrus tissue usually occurs by zoospores, which are released from sporangia in the presence of free water (25). In addition to soil moisture, disease development and severity within a citrus planting can be affected by rootstock (17), seasonal differences in rootstock susceptibility to $P$. citrophthora and $P$. nicotianae $(10,11)$, and soil temperature $(12,13)$. Disease management within infected citrus plantings is achieved by avoiding overirrigation (27), facilitating soil drainage (27), and using systemic fungicides such as

Corresponding author: M. E. Matheron

E-mail: matheron@ag.arizona.edu

Accepted for publication 22 September 2008.

doi:10.1094/PDIS-93-1-0043

(C) 2009 The American Phytopathological Society
fosetyl-Al (Aliette, Bayer CropSciences, Research Triangle Park, NC) and mefenoxam (Ridomil Gold, Syngenta Crop Protection, Inc., Greensboro, NC) (25).

During the life of a citrus planting, the population of Phytophthora pathogens can build to significant levels in orchard soil. When this orchard is removed and replanted, the residual population of Phytophthora remaining in soil can infect the new trees, resulting in suppressed growth and possible tree death, delayed onset of commercial fruit yields, and long-term decrease in yield and tree growth compared to trees growing in the absence of the pathogen. Utilization of fallow periods with or without a cover crop or soil fumigation are potential means of reducing the population of Phytophthora, so that newly planted trees can grow without the deleterious influence of these organisms.

In Arizona, several different methods are used by growers to prepare land for replanting of citrus trees. One approach involves total removal of old trees, including as many roots as possible, followed by rapid replanting without any additional treatment of soil. An alternative approach is to treat soil after tree and root removal with a soil fumigant such as metam sodium before replanting the orchard. Additional practices include leaving the soil fallow or planting the former orchard site to alfalfa (Medicago sativa L.) for 1 to 3 years before replanting with citrus. It is unknown how these different cultural practices affect the final population of Phy- tophthora present in soil prior to establishment of another citrus planting. The objective of this research was to examine the impact of different nonchemical cultural practices on survival of $P$. nicotianae, the most prevalent Phytophthora sp. in Arizona citrus groves, in soil formerly planted to citrus (16).

\section{MATERIALS AND METHODS}

Survival of $P$. nicotianae in citrus orchard soil. For each of the five experiments described below, a 15-liter capacity container was filled with a sandy loam soil collected from within the drip line of each of 8 (experiment 1), 9 (experiment 2), or 10 (experiments 3 to 5) different trees within a mature lemon (Citrus limon (L.) N.L. Burm.) grove at least 20 years old in Yuma, AZ. The soil sample from each tree was thoroughly mixed and tested for the presence of $P$. nicotianae by adding 500 $\mathrm{cm}^{3}$ of soil into a container $(13 \mathrm{~cm}$ wide $\times$ $23 \mathrm{~cm}$ long $\times 7 \mathrm{~cm}$ deep), then placing two ripe but green-colored unblemished pear fruit on the surface of the soil. Sufficient water was added to establish a $1-$ to $2-\mathrm{cm}$ layer of free water at the soil surface. After incubation at $26^{\circ} \mathrm{C}$ for $48 \mathrm{~h}$, the fruits were removed from the soil, washed in water, and incubated for an additional 48 to $96 \mathrm{~h}$ at $26^{\circ} \mathrm{C}$. Firm brown lesions developed on pear fruits invaded by $P$. nicotianae. To confirm the identity of the pathogen, a small piece of tissue from the advancing margin of one or more lesions per pear fruit was placed on corn meal agar amended with pimaricin, ampicillin, rifampicin, and pentachloronitrobenzene (PARP) (5) and observed for mycelial growth characteristics of $P$. nicotianae.

Four 1-liter subsamples of soil from each bulk sample collected from a citrus tree became samples of soil subjected to one of the following cultural conditions: (i) planted with a Citrus volkameriana Tan. \& Pasq. seedling, maintained in the greenhouse, and irrigated as needed; (ii) planted with an alfalfa seedling, maintained in the greenhouse, and irrigated as needed; (iii) maintained in the greenhouse and irrigated at the same time as soil containing citrus or alfalfa plants; and (iv) soil maintained outside without irrigation in full sun within a 1-liter capacity container composed of white plastic $(11 \mathrm{~cm}$ diameter $\times 13 \mathrm{~cm}$ deep) placed in the field so that the upper lip was $1 \mathrm{~cm}$ higher than the surrounding soil surface and the soil within the container. In all but experiment 1, a 7-liter 
capacity container composed of black plastic and containing drain holes in the bottom $(15 \mathrm{~cm} \times 15 \mathrm{~cm} \times 38 \mathrm{~cm}$ deep $)$ also was placed in the field and filled with soil collected from citrus trees so that the upper lip of the container also was $1 \mathrm{~cm}$ higher than the surrounding soil surface and the soil within the container. The purpose of maintaining soil in these different environmental conditions was to simulate what could happen after a citrus planting is removed, including rapid replanting of another citrus planting, planting the field to alfalfa, or subjecting the land to an extended period of dry fallow. In three experiments, the soil samples were subjected to these cultural conditions during the summer, in comparison with two experiments which were initiated in the winter. All citrus and alfalfa seedlings used in this study were started and maintained in a peat-based potting mix (Aqua Guard, St. Louis, MO) in a greenhouse before being transplanted into citrus orchard soil.

After the treatment phase of each experiment, where soil samples had been subjected to the various environmental conditions for 104 to 177 days (Table 1) depending on the experiment, all samples in 1-liter containers not yet in the greenhouse were placed there, and a 2-monthold C. jambhiri Lush. (rough lemon) seedling was planted into each container in experiment 1, while 6-month-old seedlings of C. volkameriana were used in experiments 2 to 5 . The alfalfa and citrus plants previously growing in some of the soil samples were removed and replaced with these citrus seedlings as well. For soil within each 7-liter container, a 1-liter volume was collected from the top (5 to 10 cm depth), middle (15 to $20 \mathrm{~cm}$ depth), and bottom (25 to $30 \mathrm{~cm}$ depth) of each container and planted with a citrus seedling. All plants were watered as needed and maintained in the greenhouse until each experiment was terminated, which ranged from 85 to 182 days (Table 1). This incubation period with the citrus host was designed to allow time for multiplication of propagules of $P$. nicotianae that may have been below detectable levels in soil subjected to a dry summer fallow period.

The sandy loam soil in each container was tested for the presence of $P$. nicotianae once during the soil treatment phase (from 31 to 104 days after soil treatments were initiated, depending on the experiment) and again at the conclusion of each experiment after the incubation period with the citrus host. For each replicate soil sample, a 50-g amount was placed into a 500 $\mathrm{ml}$ capacity container $(10 \mathrm{~g}$ of soil placed into each of two $500 \mathrm{ml}$ containers for experiment 1). An unblemished green but ripe pear fruit was placed in each container along with enough tap water to half submerge the fruit. Depending on fruit size, 265 to $300 \mathrm{ml}$ of water was added to each container. After a 48 -h incubation period on the laboratory bench at $26^{\circ} \mathrm{C}$, pear fruits were removed from the water and soil mixture and placed on the laboratory bench for an additional 5 days. One or more lesions appearing on a pear fruit and caused by $P$. nicotianae was considered positive detection of the pathogen. Data recorded included the number of replicate soil samples per treatment from which $P$. nicotianae was recovered with the pear bait assay and the mean number of lesions per pear fruit bait. Temperature of soil samples as well as rainfall during these trials also was recorded. Additionally, soil temperatures during the summer were collected at a depth of $10 \mathrm{~cm}$ from a mature citrus grove, an established alfalfa field, and a nonplanted field in Yuma.

$P$. nicotianae detection limit for pear fruit bioassay. Laboratory experiments were conducted to estimate the sensitivity of the pear fruit baiting technique for detecting zoospores of $P$. nicotianae. An isolate of $P$. nicotianae recovered from a citrus grove in Yuma was used in these trials. Four 5-mm-diameter agar disks containing mycelium from an actively growing 3-day-old culture of $P$. nicotianae on V8 juice agar (14) maintained at $24^{\circ} \mathrm{C}$ in darkness were placed into each of six plastic petri dishes $(60 \mathrm{~mm}$ diameter $)$. Seven milliliters of a nonsterile soil extract then was added to each dish. Nonsterile soil extract was prepared by mixing $15 \mathrm{~g}$ of a sandy loam orchard soil in 1 liter of distilled water with a magnetic stirrer for 8 $\mathrm{h}$ at $25 \pm 2{ }^{\circ} \mathrm{C}$. After an additional 16-h incubation period without stirring, the coarse soil particles settled to the bottom of the container and the remaining suspension was decanted and used as the soil extract. Petri dishes containing mycelial disks and soil extract were then incubated at $26^{\circ} \mathrm{C}$ in darkness for 4 days. The resulting sporangia that were produced were induced to release zoospores by chilling at $4^{\circ} \mathrm{C}$ for $30 \mathrm{~min}$. After rewarming at $25^{\circ} \mathrm{C}$ for $15 \mathrm{~min}$, the zoospore suspension in the six petri dishes was decanted into a 50 $\mathrm{ml}$ beaker. Four containers $(21 \mathrm{~cm}$ long $\times$ $11 \mathrm{~cm}$ wide $\times 7 \mathrm{~cm}$ deep) each containing $660 \mathrm{ml}$ of tap water were placed in an incubator set at $22^{\circ} \mathrm{C}$. When the temperature of the water in each container reached $22^{\circ} \mathrm{C}$, four different amounts of the zoospore suspension were added and mixed into the water in each of the four containers. Three small green but mature Bartlett pear fruits were placed into each container, resulting in fruits halfimmersed in the water. After a 48-h incubation period at $22^{\circ} \mathrm{C}$, pear fruits were removed from the zoospore suspension and incubated on the lab bench at 26 to $27^{\circ} \mathrm{C}$ for 2 days, at which time the number of lesions on each fruit caused by $P$. nicotianae was recorded. To determine the concentration of the original zoospore suspension before dispersal to the four containers, $0.5 \mathrm{ml}$ of the suspension was added to $99 \mathrm{ml}$ of water. After thorough mixing, a $0.5-\mathrm{ml}$ aliquot was distributed evenly over the surface within each of four 100-mm-diameter plastic petri dishes containing corn meal agar amended with vancomycin-pimaricin-pentachloronitrobenzene medium (19). These petri dishes, with lids removed, were maintained in a laminar-flow hood for $5 \mathrm{~min}$ to remove free moisture from the agar surface. Petri dishes then were incubated in darkness for $48 \mathrm{~h}$ at $24^{\circ} \mathrm{C}$, after which the number of pathogen colonies developing from zoospores was determined. This value was used in turn to determine the concentration of the original zoospore suspension as well as the quantity of zoospores within each container with pear fruits. This trial was conducted three times.

Analysis of data. CoStat statistical software (CoHort Software, Monterey, CA) was used to perform analysis of variance with the GLM procedure. Means were compared and separated at $P=0.05$ according to Fisher's protected least significant difference (LSD). Linear regression analysis was performed by using the SigmaPlot software package (Systat Software, Inc., San Jose, CA) to show the relationship of zoospore concentration to the number of zoospore infections detected on a pear fruit, and to predict the limit of zoospore detection by the pear fruit bait assay.

Table 1. Experimental parameters for studies evaluating survival of Phytophthora nicotianae in citrus orchard soil

\begin{tabular}{|c|c|c|c|c|}
\hline \multirow[b]{2}{*}{ Experiment number } & \multicolumn{2}{|c|}{$\begin{array}{c}\text { Duration of soil samples exposure to various cultural } \\
\text { conditions }\end{array}$} & \multicolumn{2}{|c|}{$\begin{array}{l}\text { Duration of time after soil exposure to various cultural } \\
\text { conditions until termination of trial }\end{array}$} \\
\hline & Dates & Total days & Dates & Total days \\
\hline 1 & 19 Jun to $13 \operatorname{Dec} 1998$ & 177 & 14 Dec 1998 to 8 Mar 1999 & 85 \\
\hline 2 & 5 Jul to 4 Nov 1999 & 122 & 5 Nov 1999 to 21 Apr 2000 & 158 \\
\hline 3 & $24 \mathrm{Jul}$ to 30 Nov 2000 & 129 & 1 Dec 2000 to 9 Mar 2001 & 98 \\
\hline 4 & 30 Nov1999 to 21 Mar 2000 & 104 & $22 \mathrm{Mar}$ to $17 \mathrm{Jul} 2000$ & 118 \\
\hline 5 & 4 Dec 2000 to 28 Mar 2001 & 115 & 29 Mar to 27 Sep 2001 & 182 \\
\hline
\end{tabular}




\section{RESULTS}

Survival of $P$. nicotianae in citrus orchard soil. For the three trials initiated in the summer (Table 1), P. nicotianae was not recovered after a period of 31 to 45 days from any of the soil samples main- tained outside within a 1-liter capacity container in full sunlight and not irrigated (Tables 2 to 4). Total rainfall recorded during the time that these soil samples were maintained outside was 57.9, 15.2, and $30.0 \mathrm{~mm}$ for experiments 1,2 , and 3 , respectively. The mean temperature of the soil at a depth of $10 \mathrm{~cm}$ during this time ranged from 37 to $39^{\circ} \mathrm{C}$ for the three experiments. In comparison, the pathogen was recovered from a high proportion of soil samples within same-sized containers

Table 2. Detection of Phytophthora nicotianae in citrus grove soil after subjection to different temperature, moisture, and cultural conditions from June through December 1998 (experiment 1)

\begin{tabular}{|c|c|c|c|c|c|}
\hline \multirow[b]{2}{*}{ Soil treatment ${ }^{w}$} & \multicolumn{2}{|c|}{$\begin{array}{l}31 \text { Days after initiation of soil } \\
\text { cultural treatments }^{x}\end{array}$} & \multirow{2}{*}{$\begin{array}{c}\text { Mean soil } \\
\text { temperature } \\
\left({ }^{\circ} \mathrm{C}\right) \text { during } \\
\text { 31-day period }\end{array}$} & \multicolumn{2}{|c|}{$\begin{array}{l}85 \text { Days after termination } \\
\text { of soil cultural treatments }\end{array}$} \\
\hline & $\begin{array}{l}\text { Samples with } \\
P \text {. nicotianae } \\
\text { detected }\end{array}$ & $\begin{array}{c}\text { Mean no. } \\
\text { of lesions } \\
\text { on pear bait }\end{array}$ & & $\begin{array}{l}\text { Samples with } \\
P . \text { nicotianae } \\
\text { detected }\end{array}$ & $\begin{array}{c}\text { Mean no. } \\
\text { of lesions } \\
\text { on pear bait }\end{array}$ \\
\hline $\begin{array}{l}\text { Soil in 1-liter container in greenhouse with Citrus } \\
\text { volkameriana seedling, irrigated as needed }\end{array}$ & $5 \mathrm{a}^{\mathrm{z}}$ & 1.2 & 28 & $3 \mathrm{ab}$ & 0.9 \\
\hline $\begin{array}{l}\text { Soil in 1-liter container in greenhouse with alfalfa plant, } \\
\text { irrigated as needed }\end{array}$ & $5 \mathrm{a}$ & 2.4 & 28 & $4 \mathrm{a}$ & 1.0 \\
\hline $\begin{array}{l}\text { Soil in 1-liter container in greenhouse, irrigated at the same } \\
\text { time as soil containing citrus and alfalfa plants }\end{array}$ & $1 \mathrm{~b}$ & 0.1 & 28 & $3 a b$ & 5.2 \\
\hline Soil in 1-liter container, in full sun, not irrigated & $0 \mathrm{~b}$ & 0 & 37 & $0 \mathrm{~b}$ & 0 \\
\hline
\end{tabular}

${ }^{w}$ Soil was collected from within the drip line of eight different trees within an established lemon grove. After soil from each tree was tested and found to contain P. nicotianae, four 1-liter aliquots of soil from each bulk sample became samples subjected to the listed cultural conditions. Soil samples were subjected to these conditions for 177 days (19 Jun to 13 Dec 1998), then placed in the greenhouse, and a 2-month-old C. jambhiri (rough lemon) seedling was planted into each 1-liter container. The $C$. volkameriana and alfalfa plants previously growing in some of the soil samples were removed and replaced with rough lemon seedlings as well. All plants were watered as needed until the trial was terminated 8 Mar 1999. Total rainfall from 19 Jun to 13 Dec was $57.9 \mathrm{~mm}$.

${ }^{x}$ Soil samples were tested for the presence of P. nicotianae 31 days after soil treatments were initiated (22 Jul 1998) and again 85 days after termination of the soil treatments and planting of rough lemon seedlings (8 Mar 1999). For each replicate soil sample, a 10-g amount was placed into each of two 500-ml containers. An unblemished green but ripe pear fruit was placed in each container along with enough tap water to half submerge the fruit. After a 48-h incubation period on the laboratory bench at $26^{\circ} \mathrm{C}$, pear fruits were removed from the water and soil mixture and placed on the laboratory bench for an additional 5 days. One or more lesions appearing on a pear fruit and caused by P. nicotianae was considered positive detection of the pathogen. Each value is either the number of the eight replicate soil samples per treatment from which $P$. nicotianae was recovered with the pear-bait assay or the mean number of lesions per pear-fruit bait.

${ }^{y}$ Mean soil temperature $\left({ }^{\circ} \mathrm{C}\right)$ at a depth of $10 \mathrm{~cm}$ during this 31 -day period.

${ }^{\mathrm{z}}$ Numbers in each column followed by a different letter are significantly different $(P=0.05)$ according to the Fisher's protected LSD.

Table 3. Detection of Phytophthora nicotianae in citrus grove soil after subjection to different temperature, moisture, and cultural conditions from July through November 1999 (experiment 2)

\begin{tabular}{|c|c|c|c|c|c|}
\hline \multirow[b]{2}{*}{ Soil treatment ${ }^{w}$} & \multicolumn{2}{|c|}{$\begin{array}{l}45 \text { Days after initiation } \\
\text { of soil treatments }\end{array}$} & \multirow{2}{*}{$\begin{array}{c}\text { Mean soil } \\
\text { temperature } \\
\left({ }^{\circ} \mathrm{C}\right) \text { during } \\
\text { 45-day period }\end{array}$} & \multicolumn{2}{|c|}{$\begin{array}{l}158 \text { Days after termination } \\
\text { of soil treatments }\end{array}$} \\
\hline & $\begin{array}{l}\text { Samples with } \\
\text { P. nicotianae } \\
\text { detected }\end{array}$ & $\begin{array}{c}\text { Mean no. } \\
\text { of lesions on } \\
\text { pear bait }\end{array}$ & & $\begin{array}{l}\text { Samples with } \\
\text { P. nicotianae } \\
\text { detected }\end{array}$ & $\begin{array}{l}\text { Mean no. } \\
\text { of lesions on } \\
\text { pear bait }\end{array}$ \\
\hline $\begin{array}{l}\text { Soil in 1-liter container in greenhouse with Citrus volkameriana } \\
\text { seedling, irrigated as needed }\end{array}$ & $7 a^{z}$ & 5.1 & 28 & $8 \mathrm{a}$ & 18.6 \\
\hline $\begin{array}{l}\text { Soil in 1-liter container in greenhouse with alfalfa plant, irrigated } \\
\text { as needed }\end{array}$ & $8 \mathrm{a}$ & 3.1 & 28 & $9 \mathrm{a}$ & 19.1 \\
\hline $\begin{array}{l}\text { Soil in 1-liter container in greenhouse, irrigated at the same time } \\
\text { as soil containing citrus and alfalfa plants }\end{array}$ & $8 \mathrm{a}$ & 11.1 & 28 & $8 \mathrm{a}$ & 20.8 \\
\hline Soil in 1-liter container, in full sun, not irrigated & $0 \mathrm{~b}$ & 0 & 38 & $0 \mathrm{~b}$ & 0 \\
\hline $\begin{array}{l}\text { Soil in 7-liter container, in full sun, not irrigated (soil at } 5 \text { to } 10 \\
\mathrm{~cm} \text { depth) }\end{array}$ & N.D. & N.D. & 38 & $0 \mathrm{~b}$ & 0 \\
\hline $\begin{array}{l}\text { Soil in 7-liter container, in full sun, not irrigated (soil at } 15 \text { to } 20 \\
\mathrm{~cm} \text { depth) }\end{array}$ & N.D. & N.D. & N.D. & $0 \mathrm{~b}$ & 0 \\
\hline $\begin{array}{l}\text { Soil in 7-liter container, in full sun, not irrigated (soil at } 25 \text { to } 30 \\
\text { cm depth) }\end{array}$ & N.D. & N.D. & 36 & $1 \mathrm{~b}$ & 0.2 \\
\hline
\end{tabular}

${ }^{\text {w }}$ Soil was collected from within the drip line of nine different trees within an established lemon grove. After soil from each tree was tested and found to contain P. nicotianae, 1- or 7-liter aliquots of soil from each bulk sample became samples subjected to the listed cultural conditions. Soil samples were subjected to these conditions for 122 days (5 Jul to 4 Nov 1999), then placed in the greenhouse, and a 6-month-old C. volkameriana seedling was planted into each 1-liter container. The C. volkameriana and alfalfa plants previously growing in some of the soil samples were removed and replaced with 6month-old C. volkameriana seedlings as well. All plants were watered as needed until the trial was terminated 21 Apr 21 2000. Rainfall from 5 Jul to 4 Nov was $15.2 \mathrm{~mm}$.

${ }^{x}$ Soil samples were tested for the presence of P. nicotianae 45 days after soil treatments were initiated (19 Aug 1999) and again 158 days after termination of the soil treatments and planting of C. volkameriana seedlings (21 Apr 2000). For each replicate soil sample, a 50-g amount was placed into a 500-ml container. An unblemished green but ripe pear fruit was placed in each container along with enough tap water to half submerge the fruit. After a 48-h incubation period on the laboratory bench at $26^{\circ} \mathrm{C}$, pear fruits were removed from the water and soil mixture and placed on the laboratory bench for an additional 5 days. One or more lesions appearing on a pear fruit and caused by P. nicotianae was considered positive detection of the pathogen. Each value is either the number of the nine replicate soil samples per treatment from which P. nicotianae was recovered with the pear-bait assay or the mean number of lesions per pear-fruit bait. N.D. = not determined.

${ }^{y}$ Mean soil temperature $\left({ }^{\circ} \mathrm{C}\right)$ at a depth of $10 \mathrm{~cm}$ during this 45 -day period.

${ }^{\mathrm{z}}$ Numbers in each column followed by a different letter are significantly different $(P=0.05)$ according to the Fisher's protected LSD. 
maintained in the greenhouse and planted with a seedling of $C$. volkameriana or alfalfa during the same time periods in all three trials (Tables 2 to 4 ). Recovery of $P$. nicotianae from irrigated soil in the greenhouse not planted to citrus or alfalfa was variable, ranging from one of eight, eight of nine, and nine of 10 samples for experiments 1,2 , and 3 , respectively. The mean temperature of soil planted to citrus, alfalfa, or irrigated without the presence of any plant for these trials ranged from 28 to $30^{\circ} \mathrm{C}$.

The mean soil temperature at a depth of $10 \mathrm{~cm}$ during the summer months for soil samples maintained outside in 1-liter containers $(11 \mathrm{~cm}$ diameter $\times 13 \mathrm{~cm}$ deep $)$ and not irrigated (experiments 1 to 3 ) ranged from 36.0 to $37.8^{\circ} \mathrm{C}$ (Table 5). The total hours during this time that soil temperatures at a depth of $10 \mathrm{~cm}$ were greater than or equal to $35.0^{\circ} \mathrm{C}$ ranged from 951 to 1,132 . The mean soil temperature at a depth of $30 \mathrm{~cm}$ during the summer months for soil samples maintained outside in 7liter capacity containers $(15 \mathrm{~cm} \times 15 \mathrm{~cm} \times$ $38 \mathrm{~cm}$ deep) and not irrigated (experiments 2 and 3) ranged from 34.0 to $35.0^{\circ} \mathrm{C}$ (Table 5). Total hours that soil temperatures at a depth of $30 \mathrm{~cm}$ were greater than or equal to $35.0^{\circ} \mathrm{C}$ ranged from 570 to 800 . Soil samples placed outside and not irrigated were maintained in this condition for 177 , 122, and 129 days for experiments 1, 2, and 3 , respectively. Soil samples for these experiments then were moved into the greenhouse, planted to citrus, maintained for an additional 85, 158, and 98 days, respectively, then tested for the presence of $P$. nicotianae. The pathogen was not recovered from any of the 27 soil samples that were maintained outside in 1-liter containers or the 19 soil samples in 7-liter capacity containers at soil depths of 5 to 10 $\mathrm{cm}$ and 15 to $20 \mathrm{~cm}$ (Tables 2 to 4). The pathogen was recovered from one of 19 soil samples maintained outside at a depth of 25 to $30 \mathrm{~cm}$. In comparison, $P$. nicotianae was recovered from a high proportion of soil samples initially planted to citrus, alfalfa, or irrigated without the presence of any plant for 177,122 , and 129 days, with mean soil temperatures ranging from 28 to $30^{\circ} \mathrm{C}$, then planted to citrus for an additional 85, 158, and 98 days, respectively. For comparison, the mean summer temperatures recorded for soil at a depth of 10 $\mathrm{cm}$ within a mature citrus grove, an established alfalfa field, and a nonplanted field in Yuma were $30.9,31.1$, and $36.9^{\circ} \mathrm{C}$, respectively.

For the two trials initiated in the winter (Table 1), $P$. nicotianae was recovered after a period of 104 and 115 days from 70 and $40 \%$ of the respective soil samples maintained outside within a 1-liter capacity container in full sunlight and not irrigated (Tables 6 and 7). Total rainfall recorded during the time that these soil samples were maintained outside was 10.9 and $74.7 \mathrm{~mm}$ for experiments 4 and 5 , respectively. The mean temperature of the soil at a depth of $10 \mathrm{~cm}$ during this time was 18 and $15^{\circ} \mathrm{C}$ for the respective experiments. Additionally, the pathogen was recovered from 80 to $100 \%$ of soil samples planted to citrus, alfalfa, or irrigated without the presence of any plant (Tables 6 and 7). The mean temperature of soil planted to citrus, alfalfa, or irrigated without the presence of any plant for these trials ranged from 18 to $20^{\circ} \mathrm{C}$.

Soil samples placed outside and not irrigated were maintained in this condition for 104 and 115 days for experiments 4 and 5, respectively. These soil samples then were moved into the greenhouse, planted to citrus, and maintained for an additional 118 and 182 days, respectively, at which time the soil samples were tested for the presence of $P$. nicotianae. The pathogen was recovered from 70 to $100 \%$ of soil samples that were maintained outside in either 1-liter containers or 7-liter capacity containers at soil depths of 5 to $30 \mathrm{~cm}$ (Tables 6 and 7).

For trials initiated in the summer, the mean number of lesions recorded on pear fruit incubated with soil samples initially planted to citrus, alfalfa, or irrigated without the presence of any plant ranged from 0.1 to $2.4,3.1$ to 11.1 , and 26.7 to 37.6 when tested during the treatment phase of experiments 1 to 3 , respectively (Tables 2 to 4). When soil samples within the same

Table 4. Detection of Phytophthora nicotianae in citrus grove soil after subjection to different temperature, moisture, and cultural conditions from July through November 2000 (experiment 3)

\begin{tabular}{|c|c|c|c|c|c|}
\hline \multirow[b]{2}{*}{ Soil treatment ${ }^{w}$} & \multicolumn{2}{|c|}{$\begin{array}{l}38 \text { Days after initiation } \\
\text { of soil treatments }{ }^{\mathrm{x}}\end{array}$} & \multirow{2}{*}{$\begin{array}{l}\text { Mean soil } \\
\text { temperature } \\
\left({ }^{\circ} \mathrm{C}\right) \text { during } \\
\text { 38-day period }\end{array}$} & \multicolumn{2}{|c|}{$\begin{array}{l}98 \text { Days after termination } \\
\text { of soil treatments }\end{array}$} \\
\hline & $\begin{array}{l}\text { Samples with } \\
\text { P. nicotianae } \\
\text { detected }\end{array}$ & $\begin{array}{l}\text { Mean no. of } \\
\text { lesions on } \\
\text { pear bait }\end{array}$ & & $\begin{array}{l}\text { Samples with } \\
P \text {. nicotianae } \\
\text { detected }\end{array}$ & $\begin{array}{l}\text { Mean no. of } \\
\text { lesions on } \\
\text { pear bait }\end{array}$ \\
\hline $\begin{array}{l}\text { Soil in 1-liter container in greenhouse with Citrus } \\
\text { volkameriana seedling, irrigated as needed }\end{array}$ & $9 a^{z}$ & 37.6 & 30 & 8 a & 3.9 \\
\hline $\begin{array}{l}\text { Soil in 1-liter container in greenhouse with alfalfa plant, } \\
\text { irrigated as needed }\end{array}$ & $9 \mathrm{a}$ & 26.7 & 30 & $9 \mathrm{a}$ & 9.9 \\
\hline $\begin{array}{l}\text { Soil in 1-liter container in greenhouse, irrigated at the } \\
\text { same time as soil containing citrus and alfalfa plants }\end{array}$ & $9 \mathrm{a}$ & 30.6 & 30 & $8 \mathrm{a}$ & 14.3 \\
\hline Soil in 1-liter container, in full sun, not irrigated & $0 \mathrm{~b}$ & 0 & 39 & $0 \mathrm{~b}$ & 0 \\
\hline $\begin{array}{l}\text { Soil in } 7 \text {-liter container, in full sun, not irrigated } \\
\text { (soil at } 5 \text { to } 10 \mathrm{~cm} \mathrm{depth)}\end{array}$ & N.D. & N.D. & 39 & $0 \mathrm{~b}$ & 0 \\
\hline $\begin{array}{l}\text { Soil in 7-liter container, in full sun, not irrigated } \\
\text { (soil at } 15 \text { to } 20 \mathrm{~cm} \text { depth) }\end{array}$ & N.D. & N.D. & N.D. & $0 \mathrm{~b}$ & 0 \\
\hline $\begin{array}{l}\text { Soil in } 7 \text {-liter container, in full sun, not irrigated } \\
\text { (soil at } 25 \text { to } 30 \mathrm{~cm} \text { depth) }\end{array}$ & N.D. & N.D. & 36 & $0 \mathrm{~b}$ & 0 \\
\hline
\end{tabular}

${ }^{\text {w}}$ Soil was collected from within the drip line of 10 different trees within an established lemon grove. After the soil from each tree was tested and found to contain P. nicotianae, 1- or 7-liter aliquots of soil from each bulk sample became samples subjected to the listed cultural conditions. Soil samples were subjected to these conditions for 129 days (24 Jul to 30 Nov 2000), then placed in the greenhouse, and a 6-month-old C. volkameriana seedling was planted into each 1-liter container. The C. volkameriana and alfalfa plants previously growing in some of the soil samples were removed and replaced with 6month-old $C$. volkameriana seedlings as well. All plants were watered as needed until the trial was terminated 9 Mar 2001. Rainfall from 24 Jul to 30 Nov was $30.0 \mathrm{~mm}$.

${ }^{x}$ Soil samples were tested for the presence of P. nicotianae 38 days after soil treatments were initiated (31 Aug 2000) and again 98 days after termination of the soil treatments and planting of $C$. volkameriana seedlings (9 Mar 2001). For each replicate soil sample, a 50-g amount was placed into a 500-ml container. An unblemished green but ripe pear fruit was placed in each container along with enough tap water to half submerge the fruit. After a 48-h incubation period on the laboratory bench at $26^{\circ} \mathrm{C}$, pear fruits were removed from the water and soil mixture and placed on the laboratory bench for an additional 5 days. One or more lesions appearing on a pear fruit and caused by P. nicotianae was considered positive detection of the pathogen. Each value is either the number of the 10 replicate soil samples per treatment from which P. nicotianae was recovered with the pear-bait assay or the mean number of lesions per pear-fruit bait. N.D. $=$ not determined.

${ }^{y}$ Mean soil temperature $\left({ }^{\circ} \mathrm{C}\right)$ at a depth of $10 \mathrm{~cm}$ during this 38 -day period.

${ }^{\mathrm{z}}$ Numbers in each column followed by a different letter are significantly different $(P=0.05)$ according to the Fisher's protected LSD. 
respective experiments were tested again at the conclusion of each experiment, the mean number of lesions per pear fruit ranged from 0.9 to $5.2,18.6$ to 20.8 , and 3.9 to 14.3 . For the two trials initiated in the winter, the mean number of lesions per pear fruit incubated with soil samples initially planted to citrus, alfalfa, or irrigated without the presence of any plant ranged from 4.2 to 6.8 and 11.1 to 13.1 when tested during the treatment phase and 2.2 to 17.1 and 7.7 to 9.9 when tested at the conclusion of experiments 4 and 5, respectively (Tables 6 and 7). The mean number of lesions from pear fruit incubated with soil initially subjected to a dry fallow period during the winter ranged from 2.9 to 8.6 and 4.7 to 8.0 when tested at the con-

Table 5. Comparison of soil temperature of citrus grove soil containing Phytophthora nicotianae and subjected to different cultural conditions with subsequent detection of the pathogen

\begin{tabular}{|c|c|c|c|c|c|c|c|c|c|}
\hline \multirow[b]{2}{*}{$\begin{array}{l}\text { Soil treatment and depth of temperature } \\
\text { measurementy }\end{array}$} & \multirow[b]{2}{*}{$\begin{array}{l}\text { Mean summer } \\
\text { soil temp. }\left({ }^{\circ} \mathbf{C}\right)^{\mathrm{z}}\end{array}$} & \multicolumn{6}{|c|}{$\begin{array}{l}\text { Total hours that soil was within } \\
\text { a temperature range }\left({ }^{\circ} \mathrm{C}\right) \text { of }\end{array}$} & \multirow[b]{2}{*}{$\begin{array}{l}\text { Total h } \\
\geq 3^{\circ} \mathbf{C}\end{array}$} & \multirow{2}{*}{$\begin{array}{c}\text { Samples } \\
\text { with } P . \\
\text { nicotiana } \\
\text { detected }\end{array}$} \\
\hline & & $\begin{array}{l}35.0- \\
37.9\end{array}$ & $\begin{array}{r}38.0- \\
40.9\end{array}$ & $\begin{array}{l}41.0- \\
43.9\end{array}$ & $\begin{array}{l}44.0- \\
46.9\end{array}$ & $\begin{array}{r}47.0- \\
49.9\end{array}$ & $\begin{array}{l}\mathbf{5 0 . 0}- \\
\mathbf{5 2 . 9}\end{array}$ & & \\
\hline $\begin{array}{l}\text { Soil in 1-liter container, full sun, not irrigated. } \\
\text { (experiment } 1 \text { ) }\end{array}$ & 37.8 & 397 & 292 & 205 & 192 & 46 & 0 & 1,132 & 0 \\
\hline $\begin{array}{l}\text { Soil in 1-liter container, full sun, not irrigated. } \\
\text { (experiment } 2 \text { ) }\end{array}$ & 37.0 & 339 & 350 & 333 & 171 & 0 & 0 & 1,193 & 0 \\
\hline $\begin{array}{l}\text { Soil in 1-liter container, full sun, not irrigated. } \\
\text { (experiment } 3 \text { ) }\end{array}$ & 36.0 & 396 & 298 & 151 & 106 & 0 & 0 & 951 & 0 \\
\hline $\begin{array}{l}\text { Soil in 7-liter container, full sun, not irrigated. } \\
\text { (experiment } 3 \text { ) }\end{array}$ & 34.0 & 762 & 38 & 0 & 0 & 0 & 0 & 800 & 0 \\
\hline $\begin{array}{l}\text { Soil in 7-liter container, full sun, not irrigated. } \\
\text { (experiment } 2 \text { ) }\end{array}$ & 35.0 & 570 & 0 & 0 & 0 & 0 & 0 & 570 & 1 \\
\hline $\begin{array}{l}\text { Soil in 1-liter container in greenhouse with Citrus } \\
\text { volkameriana seedling or alfalfa, irrigated as needed. } \\
\text { (experiment } 1 \text { ) }\end{array}$ & 29.2 & 185 & 67 & 0 & 0 & 0 & 0 & 252 & 3.5 \\
\hline $\begin{array}{l}\text { Soil in 1-liter container in greenhouse with Citrus } \\
\text { volkameriana seedling or alfalfa, irrigated as needed. } \\
\text { (experiment } 3 \text { ) }\end{array}$ & 29.0 & 94 & 46 & 0 & 0 & 0 & 0 & 140 & 8.5 \\
\hline $\begin{array}{l}\text { Soil in 1-liter container in greenhouse with Citrus } \\
\text { volkameriana seedling or alfalfa, irrigated as needed. } \\
\text { (experiment } 2 \text { ) }\end{array}$ & 28.0 & 109 & 19 & 3 & 0 & 0 & 0 & 131 & 8.5 \\
\hline
\end{tabular}

${ }^{y}$ Soil temperature was measured at a depth of 10 and $30 \mathrm{~cm}$ for soil in 1- and 7-liter containers, respectively.

${ }^{\mathrm{z}}$ Mean temperature during the summer months (June to September) in which each experiment was conducted. For experiment 1, 2, and 3, these periods of time were 19 Jun through 30 Sep, 5 Jul through 30 Sep, and 24 Jul through 30 Sep, respectively.

Table 6. Detection of Phytophthora nicotianae in citrus grove soil after subjection to different temperature, moisture, and cultural conditions from November 1999 through March 2000 (experiment 4)

\begin{tabular}{|c|c|c|c|c|c|}
\hline \multirow[b]{2}{*}{ Soil treatment ${ }^{w}$} & \multicolumn{2}{|c|}{$\begin{array}{l}104 \text { Days after initiation } \\
\text { of soil treatments }\end{array}$} & \multirow{2}{*}{$\begin{array}{l}\text { Mean soil tem- } \\
\text { perature }\left({ }^{\circ} \mathrm{C}\right) \text { dur- } \\
\text { ing the 104-day } \\
\text { period }^{\mathbf{y}}\end{array}$} & \multicolumn{2}{|c|}{$\begin{array}{l}118 \text { Days after termination } \\
\text { of soil treatments }\end{array}$} \\
\hline & $\begin{array}{l}\text { Samples with } \\
\text { P. nicotianae } \\
\text { detected }\end{array}$ & $\begin{array}{l}\text { Mean no. of } \\
\text { lesions on } \\
\text { pear bait }\end{array}$ & & $\begin{array}{l}\text { Samples with } \\
P \text {. nicotianae } \\
\text { detected }\end{array}$ & $\begin{array}{l}\text { Mean no. of } \\
\text { lesions on } \\
\text { pear bait }\end{array}$ \\
\hline $\begin{array}{l}\text { Soil in 1-liter container in greenhouse with Citrus } \\
\text { volkameriana seedling, irrigated as needed }\end{array}$ & $9 a^{z}$ & 6.8 & 20 & $10 \mathrm{a}$ & 17.1 \\
\hline $\begin{array}{l}\text { Soil in 1-liter container in greenhouse with alfalfa } \\
\text { plant, irrigated as needed }\end{array}$ & $8 \mathrm{a}$ & 6.2 & 20 & $8 \mathrm{ab}$ & 7.5 \\
\hline $\begin{array}{l}\text { Soil in 1-liter container in greenhouse, irrigated at } \\
\text { the same time as soil containing citrus and alfalfa } \\
\text { plants }\end{array}$ & $8 \mathrm{a}$ & 4.2 & 20 & $8 \mathrm{ab}$ & 2.2 \\
\hline Soil in 1-liter container, in full sun, not irrigated & $7 \mathrm{a}$ & 1.6 & 18 & $7 \mathrm{ab}$ & 8.6 \\
\hline $\begin{array}{l}\text { Soil in } 7 \text {-liter container, in full sun, not irrigated } \\
\text { (soil at } 5 \text { to } 10 \mathrm{~cm} \text { depth) }\end{array}$ & N.D. & N.D. & 18 & $8 \mathrm{ab}$ & 2.9 \\
\hline $\begin{array}{l}\text { Soil in 7-liter container, in full sun, not irrigated } \\
\text { (soil at } 15 \text { to } 20 \mathrm{~cm} \text { depth) }\end{array}$ & N.D. & N.D. & N.D. & $8 \mathrm{ab}$ & 8.3 \\
\hline $\begin{array}{l}\text { Soil in } 7 \text {-liter container, in full sun, not irrigated } \\
\text { (soil at } 25 \text { to } 30 \mathrm{~cm} \text { depth) }\end{array}$ & N.D. & N.D. & 18 & $9 \mathrm{a}$ & 5.3 \\
\hline
\end{tabular}

${ }^{\mathrm{w}}$ Soil was collected from within the drip line of 10 different trees within an established lemon grove. After the soil from each tree was tested and found to contain P. nicotianae, 1- or 7-liter aliquots of soil from each bulk sample became samples subjected to the listed cultural conditions. Soil samples were subjected to these conditions for 104 days (30 Nov 1999 to 21 Mar 2000), then placed in the greenhouse, and a 6-month-old C. volkameriana seedling was planted into each 1-liter container. The $C$. volkameriana and alfalfa plants previously growing in some of the soil samples were removed and replaced with 6-month-old C. volkameriana seedlings as well. All plants were watered as needed until the trial was terminated 17 Jul 2000. Rainfall from 30 Nov 1999 to $21 \mathrm{Mar} 2000$ was $10.9 \mathrm{~mm}$.

x Soil samples were tested for the presence of P. nicotianae 104 days after soil treatments were initiated (14 Mar 2000) and again 118 days after termination of the soil treatments and planting of C. volkameriana seedlings (17 Jul 2000). For each replicate soil sample, a 50-g amount was placed into a 500-ml container. An unblemished green but ripe pear fruit was placed in each container along with enough tap water to half submerge the fruit. After a $48 \mathrm{~h}$ incubation period on the laboratory bench at $26^{\circ} \mathrm{C}$, pear fruits were removed from the water and soil mixture and placed on the laboratory bench for an additional 5 days. One or more lesions appearing on a pear fruit and caused by P. nicotianae was considered positive detection of the pathogen. Each value is either the number of the 10 replicate soil samples per treatment from which P. nicotianae was recovered with the pear-bait assay or the mean number of lesions per pear-fruit bait. N.D. = not determined.

${ }^{y}$ Mean soil temperature $\left({ }^{\circ} \mathrm{C}\right)$ at a depth of $10 \mathrm{~cm}$ during this 104-day period.

${ }^{\mathrm{z}}$ Numbers in each column followed by a different letter are significantly different $(P=0.05)$ according to the Fisher's protected LSD. 
clusion of experiments 4 and 5, respectively.

$P$. nicotianae detection limit for pear fruit bioassay. The final concentration of zoospores per milliliter of water in the four containers for the first trial was 67.00 , $6.70,3.30$, and 0.70 ; for the second trial was 360, 36, 18.0, and 3.6; and for the third trial was $3.10,0.63,0.031$, and 0.003 . The mean number of lesions on the three pear fruits exposed to each of these concentrations of zoospores ranged from 0 for a concentration of 0.003 zoospores per $\mathrm{ml}$ of water to so many infection points that individual spots could not be discerned at a concentration of 360 zoospores per $\mathrm{ml}$ of water. Regression analysis (Fig. 1) revealed a significant linear relationship between the $\log _{10}$ values of zoospore concentration and the number of lesions caused by $P$. nicotianae that developed on pear fruits $\left(Y=14.67 \log _{10} X+0.643, r^{2}=\right.$ $0.756, P=0.005)$ when comparing concentrations of zoospores that caused on average at least one but less than 40 lesions per pear fruit. The predicted limit of detection of zoospores from the linear regression line was less than one zoospores per $\mathrm{ml}$ of water.

\section{DISCUSSION}

The objective of this research was to test the effect of different cultural practices on the survival of $P$. nicotianae in soil formerly planted to citrus, with the goal of identifying the most effective means of reducing the population of this pathogen to nondetectable levels. In three trials over a 3-year period, P. nicotianae was not detected at a depth of $10 \mathrm{~cm}$ after subjecting soil naturally infested with the pathogen to a summer dry fallow period of at least 31 days in the desert southwest region of Arizona. The mean temperature of soil at this depth for the three trials ranged from 37 to $39^{\circ} \mathrm{C}$, which was similar to the mean summer temperature of $37^{\circ} \mathrm{C}$ recorded at the same depth in a nonplanted field in Yuma. Furthermore, in two of these trials, where soil was subjected to a summer dry fallow for 38 and 45 days, the pathogen could not be detected at a depth of 15 to $20 \mathrm{~cm}$ and was detected in only one of 19 soil samples at a depth of 25 to $30 \mathrm{~cm}$. The mean maximum and minimum daily air temperatures were 41 and $26^{\circ} \mathrm{C}$, respectively, during July and August in the region where these trials were conducted. The abundance of high temperatures during the summer facilitates the heating of soil to levels attainable only by soil solarization with plastic in other areas with more moderate climates. Although not experimentally addressed, deep tillage of soil after approximately 1 month to move soil below a depth of $30 \mathrm{~cm}$ to a shallower depth may increase the efficiency of the overall summer fallow treatment at depths at or below $30 \mathrm{~cm}$.

In contrast to the dry summer fallow treatment, a dry winter fallow treatment did not reduce the population of the pathogen to nondetectable levels. The mean temperature of soil at a depth of $10 \mathrm{~cm}$ during the treatment period for the two trials initiated in the winter was 18 and $20^{\circ} \mathrm{C}$. Furthermore, growing alfalfa in soil containing P. nicotianae from 104 to 177 days during any time of the year did not lead to reduced detection of the pathogen compared to soil containing citrus, which would be considered the control in this study. In the three greenhouse trials initiated in the summer as well as in a mature citrus grove and alfalfa field, the mean summer temperature of soil at a depth of

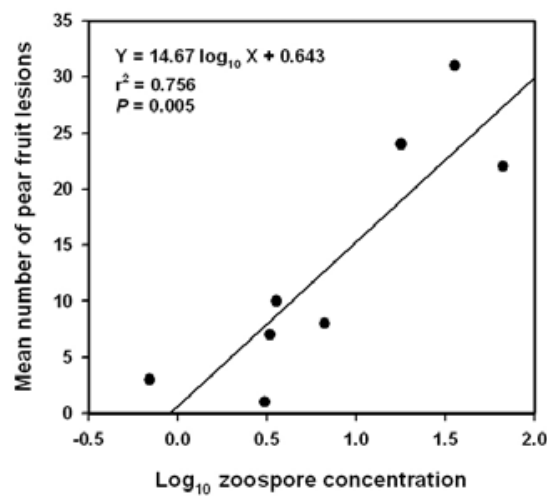

Fig. 1. Relationship of concentration of Phytophthora nicotianae zoospores in incubation water to number of infection lesions detected on pear fruit bait.

Table 7. Detection of Phytophthora nicotianae in citrus grove soil after subjection to different temperature, moisture, and cultural conditions from December 2000 through March 2001 (experiment 5)

\begin{tabular}{|c|c|c|c|c|c|}
\hline \multirow[b]{2}{*}{ Soil treatment ${ }^{w}$} & \multicolumn{2}{|c|}{$\begin{array}{l}115 \text { Days after initiation } \\
\text { of soil treatments }\end{array}$} & \multirow{2}{*}{$\begin{array}{c}\text { Mean soil } \\
\text { temperature } \\
\left({ }^{\circ} \text { C) during the }\right. \\
\text { 115-day period }\end{array}$} & \multicolumn{2}{|c|}{$\begin{array}{l}182 \text { Days after termination } \\
\text { of soil treatments }\end{array}$} \\
\hline & $\begin{array}{l}\text { Samples with } \\
\text { P. nicotianae } \\
\text { detected }\end{array}$ & $\begin{array}{l}\text { Mean no. of } \\
\text { lesions on } \\
\text { pear bait }\end{array}$ & & $\begin{array}{l}\text { Samples with } \\
\text { P. nicotianae } \\
\text { detected }\end{array}$ & $\begin{array}{c}\text { Mean no. of } \\
\text { lesions on } \\
\text { pear bait }\end{array}$ \\
\hline $\begin{array}{l}\text { Soil in 1-liter container in greenhouse with Citrus } \\
\text { volkameriana seedling, irrigated as needed }\end{array}$ & $10 \mathrm{a}^{\mathrm{z}}$ & 11.5 & 18 & $9 \mathrm{a}$ & 8.0 \\
\hline $\begin{array}{l}\text { Soil in 1-liter container in greenhouse with alfalfa } \\
\text { plant, irrigated as needed }\end{array}$ & $10 \mathrm{a}$ & 13.1 & 18 & $8 \mathrm{a}$ & 9.9 \\
\hline $\begin{array}{l}\text { Soil in 1-liter container in greenhouse, irrigated at the } \\
\text { same time as soil containing citrus and alfalfa plants }\end{array}$ & $10 \mathrm{a}$ & 11.1 & 18 & $10 \mathrm{a}$ & 7.7 \\
\hline Soil in 1-liter container, in full sun, not irrigated & $4 \mathrm{~b}$ & 1.1 & 15 & $8 \mathrm{a}$ & 4.7 \\
\hline $\begin{array}{l}\text { Soil in 7-liter container, in full sun, not irrigated } \\
\text { (soil at } 5 \text { to } 10 \mathrm{~cm} \text { depth) }\end{array}$ & N.D. & N.D. & 15 & $9 \mathrm{a}$ & 7.9 \\
\hline $\begin{array}{l}\text { Soil in 7-liter container, in full sun, not irrigated } \\
\text { (soil at } 15 \text { to } 20 \mathrm{~cm} \text { depth) }\end{array}$ & N.D. & N.D & N.D. & $9 \mathrm{a}$ & 6.2 \\
\hline $\begin{array}{l}\text { Soil in 7-liter container, in full sun, not irrigated } \\
\text { (soil at } 25 \text { to } 30 \mathrm{~cm} \text { depth) }\end{array}$ & N.D. & N.D. & 16 & $10 \mathrm{a}$ & 8.0 \\
\hline
\end{tabular}

${ }^{\text {w}}$ Soil was collected from within the drip line of 10 different trees within an established lemon grove. After the soil from each tree was tested and found to contain P. nicotianae, 1- or 7-liter aliquots of soil from each bulk sample became samples subjected to the listed cultural conditions. Soil samples were subjected to these conditions for 115 days (4 Dec 2000 to 28 Mar 2001), then placed in the greenhouse, and a 6-month-old C. volkameriana seedling was planted into each 1-liter container. The $C$. volkameriana and alfalfa plants previously growing in some of the soil samples were removed and replaced with 6-month-old C. volkameriana seedlings as well. All plants were watered as needed until the trial was terminated 27 Sep 2001 . Rainfall from 4 Dec 2000 to 28 Mar 2001 was $74.7 \mathrm{~mm}$.

${ }^{x}$ Soil samples were tested for the presence of $P$. nicotianae 115 days after soil treatments were initiated (28 Mar 2001) and again 182 days after termination of the soil treatments and planting of $C$. volkameriana seedlings (27 Sep 2001). For each replicate soil sample, a 50-g amount was placed into a 500-ml container. An unblemished green but ripe pear fruit was placed in each container along with enough tap water to half submerge the fruit. After a 48-h incubation period on the laboratory bench at $26^{\circ} \mathrm{C}$, pear fruits were removed from the water and soil mixture and placed on the laboratory bench for an additional 5 days. One or more lesions appearing on a pear fruit and caused by P. nicotianae was considered positive detection of the pathogen. Each value is either the number of the 10 replicate soil samples per treatment from which $P$. nicotianae was recovered with the pear-bait assay or the mean number of lesions per pear-fruit bait. N.D. = not determined.

${ }^{y}$ Mean soil temperature $\left({ }^{\circ} \mathrm{C}\right)$ at a depth of $10 \mathrm{~cm}$ during this 115 -day period.

${ }^{\mathrm{z}}$ Numbers in each column followed by a different letter are significantly different $(P=0.05)$ according to the Fisher's protected LSD. 
$10 \mathrm{~cm}$ ranged from 28 to $31^{\circ} \mathrm{C}$. Soil temperatures in this range have been shown to be ineffective in significantly reducing the population of $P$. nicotianae in soil (1). The effect of a 1- to 3-year rotation to alfalfa between citrus plantings was not assessed in this trial; therefore, the effect of this cultural practice on the population of $P$. nicotianae is unknown. Alfalfa is not a recognized host for $P$. nicotianae in the United States, although the pathogen was associated with a root rot on lucerne in Australia (22).

Temperatures achieved during soil solarization have been sufficient to inactivate propagules of $P$. nicotianae $(1,18), P$. cinnamomi $(4,20)$, and $P$. capsici (3) as well as reduce the incidence of diseases caused by these pathogens. Differences in methods of solarization, experimental design, and presentation of data make direct comparisons of studies difficult; however, maximum daily temperatures of $40^{\circ} \mathrm{C}$ or higher at a soil depth of $5 \mathrm{~cm}$ during the 1to 2-month solarization periods for a major portion of the solarization period were necessary to achieve significant inactivation of these pathogens. Coelho et al. (1) found that the time required to reduce soil populations of $P$. nicotianae to residual levels decreased with increasing temperatures. Similar findings occurred in the present study, where $P$. nicotianae was not recovered from any soil sample originally containing this pathogen that was maintained in full sun, not irrigated, and subjected to temperatures ranging from 35.0 to $40.9^{\circ} \mathrm{C}$ for $800 \mathrm{~h}$ compared to the same result for soil subjected to temperatures ranging from 41.0 to $46.9^{\circ} \mathrm{C}$ for at least $257 \mathrm{~h}$.

The effectiveness of soil solarization is a function of the thermal dose (21), which is derived from the interaction of temperature, exposure time, thermal sensitivity of the organism, and the chemical, physical, and biological characteristics of the soil, including moisture content (23). The same parameters affect the thermal dose in the summer fallow treatment, which was essentially soil solarization without plastic. A plastic covering over soil to be solarized is used to suppress the loss of heat and moisture from soil (6). In the dry summer fallow treatment, total rainfall amounts of 56, 10 , and $29 \mathrm{~mm}$ were recorded during the summer days that these soil samples were maintained outside during 1998, 1999, and 2000 , respectively. Soil moisture during the summer fallow treatment was not recorded in this study; however, in earlier work on the effect of dry soil on viability of sclerotia of Sclerotinia minor and $S$. sclerotiorum in the desert in Yuma, water potential levels $\leq-100 \mathrm{MPa}$ were recorded for nonirrigated soil during the summers of 1996 to 1998 in nonirrigated soil (15). The findings of the current study suggest that sufficiently high temperature, but not high soil moisture, is required to inactivate $P$. nicotianae.
The identity and quantity of the different types of $P$. nicotianae propagules present in soil were not assessed in this study; however, Lutz and Menge (9) reported that the types of propagules of $P$. nicotianae ( $P$. parasitica) that occur in irrigated California citrus groves include sporangia, zoospore cysts, chlamydospores, and oospores. Of these, chlamydospores and oospores are considered long-term survival propagules in soil, and chlamydospores were the predominant long-term survival propagule (9).

Each experiment conducted in this study consisted of a soil treatment phase followed by an incubation period with the citrus host. The period of incubation with the citrus host was included to allow pathogen propagules that may exist at nondetectable levels after the summer fallow period an opportunity to multiply in the presence of citrus to levels that would be detected in a subsequent assay. During the treatment phase and at the end of the incubation period with the citrus host, a pear fruit bioassay was used to detect the presence of the pathogen in each soil sample. Plants and plant parts have been used to detect or in some cases quantify disease severity due to $P$. nicotianae and other Phytophthora spp. $(3,4,16,18,20)$. In the current study, pear fruits were incubated with various known concentrations of zoospores to determine the approximate detection limit of this assay for $P$. nicotianae in soil. The limit of detection indicated by the linear regression of the data was less than one zoospore per $\mathrm{ml}$ of water.

Using the detection limit for zoospores determined by the pear fruit bioassay in the laboratory to ascertain the detection limit for propagules of $P$. nicotianae present in soil samples cannot be accurately accomplished due to the following factors. Firstly, in soil subjected to a dry period, the presumptive surviving propagules would be chlamydospores and perhaps oospores if present (9). Detection of these propagules would only occur if they produced sporangia, which in turn liberated zoospores that infected the pear fruit bait within the 48-h period that the pear fruit was incubated with soil. Furthermore, indirect detection of these propagules would be affected by the number of zoospores produced from a sporangium originating from a chlamydospore or an oospore in soil. Finally, irrigated soil supporting growth of citrus or other hosts of $P$. nicotianae may contain encysted zoospores and sporangia in addition to chlamydospores and oospores, further complicating determination of the detection limit of $P$. nicotianae in these situations. As noted by Erwin and Ribeiro (2), an extended baiting period may overestimate inoculum density, as the primary inoculum, which probably exists as oospores or chlamydospores, will produce sporangia and subsequently many zoo- spores, each of which is a colony-forming unit. Due to the noted complications in using the pear fruit bioassay as a measure of inoculum density of $P$. nicotianae in soil, only the data on positive or negative detection of the pathogen were considered relevant in this study, not the quantitative number of lesions recorded from pear fruits incubated with soil.

In regions with a hot and dry summer climate, the findings of this study suggest that a dry summer fallow treatment of soil after removal of an existing citrus planting and before establishment of a new citrus grove would provide a rapid and relatively inexpensive means of reducing the population of $P$. nicotianae to virtually nondetectable levels, at least to a depth of $30 \mathrm{~cm}$. Traditional soil solarization could be employed in areas where summer temperatures are not high enough to heat soil to a sufficient degree without the use of a plastic cover. If found to be efficacious in future studies, crop rotation could be a longer term approach to significantly reducing the population of this pathogen; however, care would have to be taken to avoid planting any of the many known hosts of $P$. nicotianae (2). A long-term period of crop rotation with plants that are not hosts for $P$. nicotianae was not tested in this study.

\section{LITERATURE CITED}

1. Coelho, L., Mitchell, D. J., and Chellemi, D. O. 2000. Thermal inactivation of Phytophthora nicotianae. Phytopathology 90:1089-1097.

2. Erwin, D. C., and Ribeiro, O. K. 1996. Phytophthora Diseases Worldwide. American Phytopathological Society, St. Paul, MN.

3. French-Monar, R. D., Jones, J. B., OzoresHampton, M., and Roberts, P. D. 2007. Survival of inoculum of Phytophthora capsici in soil through time under different soil treatments. Plant Dis. 91:593-598.

4. Gallo, L., Siverio, F., and Rodriguez-Pérez, A.M. 2007. Thermal sensitivity of Phytophthora cinnamomi and long term effectiveness of soil solarisation to control avocado root rot. Ann. App. Biol. 150:65-73.

5. Jeffers, S. N., and Martin, S. B. 1986. Comparison of two media selective for Phy tophthora and Pythium species. Plant Dis. 70:1038-1043.

6. Katan, J. 1981. Solar heating (solarization) of the soil for control of soilborne pests. Annu. Rev. Phytopathol. 19:211-236.

7. Klotz, L. J. 1978. Fungal, bacterial, and nonparasitic diseases and injuries originating in the seedbed, and nursery orchard. Pages 1-66 in: The Citrus Industry. Vol. 4, Crop Protection. W. Reuther, E. C. Calavan, and G. F. Carman, eds. University of California Agricultural Sciences Publications, Richmond.

8. Klotz, L. J., DeWolfe, T. A., and Wong, P.-P. 1958. Decay of fibrous roots of citrus. Phytopathology 48:616-622.

9. Lutz, A. L., and Menge, J. A. 1991. Population fluctuations and the numbers and types of propagules of Phytophthora parasitica that occur in irrigated citrus groves. Plant Dis. 75:173-179.

10. Matheron, M. E., and Matejka, J. C. 1989. Temporal changes in susceptibility of citrus phloem tissue to colonization by Phytophthora citrophthora and $P$. parasitica. Plant Dis. 73:408-411. 
11. Matheron, M. E., and Matejka, J. C. 1993. Seasonal differences in susceptibility of three citrus rootstocks to root lesions caused by $P h y$ tophthora citrophthora and P. parasitica. Plant Dis. 77:729-732.

12. Matheron, M. E., and Porchas, M. 1992. Effects of temperature on sporulation and growth of Phytophthora citrophthora and P. parasitica and development of foot rot on citrus. Plant Dis. 76:1103-1109.

13. Matheron, M. E., and Porchas, M. 1996. Colonization of citrus roots by Phytophthora citrophthora and $P$. parasitica in daily soil temperature fluctuations between favorable and inhibitory levels. Plant Dis. 80:1135-1140.

14. Matheron, M. E., and Porchas, M. 2000. Impact of azoxystrobin, dimethomorph, fluazinam, fosetyl-Al, and metalaxyl on growth, sporulation, and zoospore cyst germination of three Phytophthora spp. Plant Dis. 84:454-458.

15. Matheron, M. E., and Porchas, M. 2005. Influence of soil temperature and moisture on eruptive germination and viability of sclerotia of Sclerotinia minor and S. sclerotiorum. Plant Dis. 89:50-54.

16. Matheron, M. E., Porchas, M., and Matejka, J.
C. 1997. Distribution and seasonal population dynamics of Phytophthora citrophthora and $P$. parasitica in Arizona citrus orchards and effect of fungicides on tree health. Plant Dis. 81:1384-1390.

17. Matheron, M. E., Wright, G. C., and Porchas, M. 1998. Resistance to Phytophthora citrophthora and $P$. parasitica and nursery characteristics of several citrus rootstocks. Plant Dis. 82:1217-1225.

18. McGovern, R. J., McSorley, R., and Urs, R. R. 2000. Reduction of Phytophthora blight of Madagascar periwinkle in Florida by soil solarization in autumn. Plant Dis. 84:185-191.

19. Mircetich, S. M., and Matheron, M. E. 1976. Phytophthora root and crown rot of cherry trees. Phytopathology 66:549-558.

20. Pinkerton, J. N., Ivors, K. L., Miller, M. L., and Moore, L. W. 2000. Effect of soil solarization and cover crops on populations of selected soilborne plant pathogens in western Oregon. Plant Dis. 84:952-960.

21. Pullman, G. S., DeVay, J. E., and Garber, R. H. 1981. Soil solarization and thermal death: A logarithmic relationship between time and temperature for four soilborne plant pathogens.
Phytopathology 71:959-964.

22. Purss, G. S. 1959. Root rot of lucerne. Queensl. Agric. J. 85:767-770

23. Stapleton, J. J., and DeVay, J. E. 1986. Soil solarization: A non-chemical approach for management of plant pathogens and pests. Crop Prot. 5:190-198.

24. Timmer, L. W. 1973. Characteristics of Phytophthora isolates from Texas citrus orchards. J. Rio Grande Valley Hortic. Soc. 27:44-48.

25. Timmer, L. W., and Menge, J. A. 1988. Phytophthora-induced diseases. Pages 22-24 in: Compendium of Citrus Diseases. J. O. Whiteside, S. M. Garnsey, and L. W. Timmer, eds. American Phytopathological Society, St. Paul, $\mathrm{MN}$.

26. Timmer, L. W., Menge, J. A., Zitko, S. E. Pond, E., Miller, S. A., and Johnson, E. L. 1993. Comparison of ELISA techniques and standard isolation methods for Phytophthora detection in citrus orchards in Florida and California. Plant Dis. 77:791-796.

27. University of California. 1991. Integrated Pest Management for Citrus. 2nd ed. Division of Agriculture and Natural Resources, Publ 3303. Oakland, CA. 